\title{
TWO SELECTIVE SPECTROPHOTOMETRIC METHODS FOR THE DETERMINATION OF THIORIDAZINE HYDROCHLORIDE IN TABLETS AND IN BIOLOGICAL FLUIDS
}

\author{
A. M. EL-DIDAMONY,"广 AND M. A. MOUSTAFA ${ }^{2}$ \\ ${ }^{1}$ Chemistry Department, Faculty of Science, Zagazig University, Zagazig, Egypt \\ ${ }^{2}$ Chemistry Department, Faculty of Science, Omar El-Moktar University, Tobruk, Libya
}

(Received: March 8, 2011 - Accepted: October 5, 2011)

\begin{abstract}
Two simple, rapid and selective spectrophotometric methods have been developed for the analysis of the psychoactive drug thioridazine $\mathrm{HCl}$ (TRH) in tablets and in biological fluids. The first method is based on the oxidation of TRH by a known excess of N- bromosuccinimide (NBS), followed by the determination of unreacted oxidants by measuring the decrease in absorbance of two different dyes; amaranth (AM) and methylene blue (MB) at a suitable $\lambda$ max 520 and $660 \mathrm{~nm}$, respectively. Beer-Lambert plots showed good correlation in the concentration ranges of $0.8-4.8$ and $0.8-5.6 \mu \mathrm{g} / \mathrm{ml}$ for AM and MB methods, respectively. The second method is based upon the formation of an ion-pair complexes (1: 1) with the acidic sulphonphthalein dyes bromophenol blue (BPB) and bromothymol blue (BTB). The formed complexes were extracted into methylene chloride and their absorbance was measured at 405 and $408 \mathrm{~nm}$ for BPB and BTB, respectively. Beer's law was obeyed with a good correlation coefficient $(r=0.9995-0.9989)$ in the concentration ranges of $4-24 \mu \mathrm{g} / \mathrm{ml}$ for both BPB and BTB methods, respectively. All measurements of the two procedures are carried out in an acidic medium at room temperature. Optimizations of the different experimental conditions are described for both methods. The two methods have been successfully applied to the determination of thioridazine $\mathrm{HCl}$ in pharmaceutical, serum and urine samples and average recoveries are in the range of $98.12-102.55 \%$. Analytical results obtained with this novel method are satisfactory.
\end{abstract}

Key words: Visible spectrophotometry, Thioridazine HCl, NBS, Sulphonphthalein Dyes, Pharmaceutical formulations, Biological fluids.

\section{INTRODUCTION}

Thioridazine hydrochloride (TRH) is a white or cream-colored, crystalline powder with a very bitter taste. It is the hydrochloride of 10-[2-(lmethyl-2piper-idyl)ethyl]-2-methylthiophenothiazine (Scheme 1), is a phenothiazine antipsychotic drug used as a tranquillizer and antidepressant in managing some psychiatric disorders without potentiate anesthetics action and therapeutically significant anti-emetic or hypothermic effects compared to other phenothiazine drugs. This drug is used mainly for treatment of schizophrenia and control of mania and agitation ${ }^{1}$. It is also used for the short-term treatment of adults with major depression who have varying degrees of associated anxiety ${ }^{2}$ and in other aspects ${ }^{3-5}$. Pharmacology research showed that thioridazine increases the rate of $\mathrm{Ca}^{2+}$ accumulation into synaptic plasma membrane vesicles ${ }^{6}$. Due to the clinical importance of thioridazine hydrochloride, it is significant to establish a simple and sensitive method for its determination in biological fluids.<smiles>CCN1c2ccccc2Sc2ccc([SH](C)C)cc21</smiles>

Scheme 1: Chemical structure of TRH

Different pharmacopoeias recommend the determination of thioridazine base or the hydrochloride by titrating the drug in glacial acetic acid and acetic anhydride against perchloric acid. The BP recommends the titration of the drug in acetone solution ${ }^{7}$. containing about $7 \%$ mercury(II) acetate solution and using methyl orange as indicator Several analytical methods have been described for determination of TRH. Among the methods, voltammetry ${ }^{8-10}$ and conventional high performance liquid chromatography ${ }^{11,12}$ are most often used. Supercritical fluid chromatography ${ }^{13}$ and HPLC combined with other techniques ${ }^{14-18}$ were reported for determination of TRH and its main metabolites or derivatives. Chemiluminescence ${ }^{19}$, electrophoresis ${ }^{20}$, spectrofluorimetric ${ }^{21}$, ${ }^{22}$ and spectrophotometry ${ }^{23-26}$ have been also reported for the determination of thioridazine hydrochloride. Some of these methods lack adequate sensitivity and some are expensive and time consuming.

The aim of this study is to develop accurate and inexpensive spectrophotometric methods that can be considered for routine determination of TRH in tablets and biological fluids. The methods were based either on the oxidation of TRH with slight excess of $\mathrm{N}$ - bromosuccinimide in acidic medium or ion-pair formation with bromophenol blue and bromothymol blue in Clark and Lubs buffer of $\mathrm{pH}$ 1.6. It is evident that the use of the ion-pair method is more preferable due to its wider usable concentration range.

\section{EXPERIMENTAL}

\section{Equipment}

An spectroscan $80 \mathrm{D}$ double-beam UV/visible spectrophotometer (Biotech Engineering Ltd., UK), with wavelength range $190 \mathrm{~nm}-1100 \mathrm{~nm}$, spectral bandwidth $2.0 \mathrm{~nm}$ with matched $10 \mathrm{~mm}$ quartz cells were used for all the absorbance spectral measurements.

Chemicals and Materials

All chemicals used were of an analytical reagent grade and solutions were made in distilled water.

i. Standard solution of thioridazine hydrochloride (TRH)

Pharmaceutical grade thioridazine hydrochloride was received as a gift from Miser Company, Cairo, Egypt; it was reported to be $99.8 \%$ pure and was used as received. A stock standard solution equivalent to $30 \mathrm{mg}$ of TRH was prepared by dissolving an accurately weighed amount of pure drug in distilled water. The solution of TRH was diluted stepwise to obtain working concentration of 200 and $100 \mu \mathrm{g} / \mathrm{ml}$ for use with NBS and acid dyes, respectively. The standard solutions were kept in amber colored bottles and stored in a refrigerator when not in use.

ii. N-bromosuccinimide (NBS)

A $0.05 \%$ of N-bromosuccinimide (Aldrich Co., Ltd., Gillingham-Dorst, Germany) was freshly prepared by dissolving an accurate weight in least amount of warm water in $100 \mathrm{ml}$ calibrated flask and then diluted with water to the mark.

iii. Amaranth (AM)

A $2.0 \times 10^{-3} \mathrm{M}$ of amaranth (E. Merck) was prepared by dissolving an accurate weight of dye in least amount of water and completed to the mark in a $100 \mathrm{ml}$ calibrated flask.

iv. Methylene blue (MB)

A $1.0 \times 10^{-3} \mathrm{M}$ of methylene blue (E. Merck) was prepared by dissolving an accurate weight of dye in least amount of water and completed to the mark in a $100 \mathrm{ml}$ calibrated flask.

v. Hydrochloric acid

A $2.0 \mathrm{M}$ of $\mathrm{HCl}$ was prepared by diluting $41.8 \mathrm{ml}$ of concentrated acid (Merck, Darmstadt, Germany, sp. gr. 1.18, $37 \%$ ) to $250 \mathrm{ml}$ with water.

vi. Sulphonphthalein dyes

A solutions of $5 \times 10^{-4} \mathrm{M}$ bromophenol blue and bromothymol blue (Aldrich product) were prepared by dissolving an accurately weight of the acid dyes 
in a few drops of acetone and then diluted to the mark with distilled water in a $100 \mathrm{ml}$ calibrated flasks separately.

vii. Buffer solutions

A series of buffer solutions of $\mathrm{KCl}-\mathrm{HCl}(\mathrm{pH} 1.0-2.2)$; $\mathrm{NaOAc}-\mathrm{HCl}$ (pH 1.99 - 5.2); $\mathrm{NaOAc}-\mathrm{AcOH}(\mathrm{pH} 3.42$ - 5.89); potassium hydrogen phthalate $-\mathrm{NaOH}(\mathrm{pH} 4-5.6)$ and $\mathrm{NaH}_{2} \mathrm{PO}_{4}-\mathrm{Na}_{2} \mathrm{HPO}_{4}(\mathrm{pH} 6.0-8.0)$ were prepared by following the standard methods.

\section{Recommended procedures and calibration curves}

a- $\quad$ Oxidation reaction using NBS

An aliquots of the working standard solutions of TRH equivalent to $(0.8-4.8 \mu \mathrm{g})$ were measured accurately and delivered into a series of $25 \mathrm{ml}$ calibrated flasks by means of micro burette. Then, $2.0 \mathrm{ml}$ of $2.0 \mathrm{M} \mathrm{HCl}$ and $0.4 \mathrm{ml}$ of $0.05 \%$ NBS were added and the mixture was left to stand for 15 min at room temperature with occasional shaking. Later, $0.9 \mathrm{ml}$ of $2.0 \times 10^{-3} \mathrm{M}$ of $\mathrm{AM}$ and $0.8 \mathrm{ml}$ of $1.0 \times 10^{-3} \mathrm{M}$ of MB solution were added and the contents were diluted to the mark with distilled water and mixed well. The absorbance was measured against a reagent blank at 520 and $660 \mathrm{~nm}$, respectively. The unknown concentration was read from the calibration graphs or computed from the regression equation derived using Beer's law data.

$b$ - $\quad$ Ion-pair methods using $B P B$ and BTB

Suitable aliquots of the stock solution of TRH (4 - $24 \mu \mathrm{g}$ for both BPB and BTB method) were transferred into separate glass-stopper tubes. Then, $2.0 \mathrm{ml}$ $\mathrm{KCl}+\mathrm{HCl}$ buffer of $\mathrm{pH} 1.6$ and $2.0 \mathrm{ml}$ of $1 \times 10^{-3} \mathrm{M} \mathrm{BPB}$ or BTB were added and mixed. The contents were extracted with $10 \mathrm{ml}$ methylene chloride. by shaking for $2.0 \mathrm{~min}$ and the organic layer was dried over anhydrous sodium sulphate. The absorbance of the yellow colored complexes was measured at 405 and $408 \mathrm{~nm}$ for BPB and BTB respectively, against a methylene chloride. In both methods, a standard graph was prepared by plotting the absorbance $v s$. the concentration of TRH.

\section{Procedure for pharmaceutical preparations}

At least twenty of TRH tablets (Thiozine tablets, Delta Pharm Company, Cairo Egypt, are labeled to contain $25 \mathrm{mg}$ of thioridazine $\mathrm{HCl}$ per tablet) were weighed to obtain the mean tablet weight and then ground to a homogenized powder. A quantity of the powdered tablets equivalent to $30 \mathrm{mg}$ was transferred into a $100 \mathrm{ml}$ calibrated flask and dissolved in distilled water and filtered. A suitable amount of filtrate was taken and analyzed as described under recommended procedures. For the proposed methods, the content of a tablet was calculated using the corresponding regression equation of the appropriate calibration graph.

\section{Procedure for spiked urine and serum}

The proposed methods were applied to the determination of TRH in spiked urine and serum provided from several healthy volunteers. Spiked urine was 50 -fold diluted with distilled water. A $10 \mathrm{ml}$ of serum sample was deproteinzed by adding $5 \mathrm{ml}$ of acetonitrile in a centrifuge for $5 \mathrm{~min}$ at $1000 \mathrm{rpm}$. The supernatant was used to investigate recovery. Add an aliquot of standard aqueous solution of TRH (200 and $100 \mu \mathrm{g} / \mathrm{ml}$ ) to $1.0 \mathrm{ml}$ of diluted urine or serum. The analysis was completed as in the recommended procedures. A blank value was determined by treating TRH-free urine and TRH-free serum in the same way. The absolute recovery was determined for TRH by comparing the representative absorbance of the treated urine or serum samples with the absorbance of the standard drug at the same concentration.

\section{RESULTS AND DISCUSSION}

Optimization of Variables

The optimum conditions for the assay procedures have been established by studying the reactions as a function of reaction time, concentration of reagents, stability of the colored species, buffer and $\mathrm{pH}$. Such variables were changed individually while the others were kept constant.

\section{a- $\quad$ Oxidation reaction using NBS}

The method is based on the fact that NBS in an acid medium directly oxidizes TRH as a member of phenothiazines, first to the intermediate blue cation-radical (reversible step). The presence of an excess of oxidants leads to generation of the colorless thioridazine sulphoxide (irreversible step) ${ }^{27-29}$. The oxidation of phenothiazines is generally represented by Scheme 2 .

The ability of NBS to oxidize TRH and bleach the colors of amaranth (AM) and methylene blue (MB) dyes has been used for the indirect spectrophotometric assay of the drug. In both methods, the drug is reacted with a known excess of NBS in an acid medium, and the unreacted oxidant is determined by reacting with a fixed amount of either AM or MB and measuring the absorbance at either $520 \mathrm{~nm}$ or $660 \mathrm{~nm}$, respectively. In either method, the absorbance increased linearly with increasing concentration of drug.
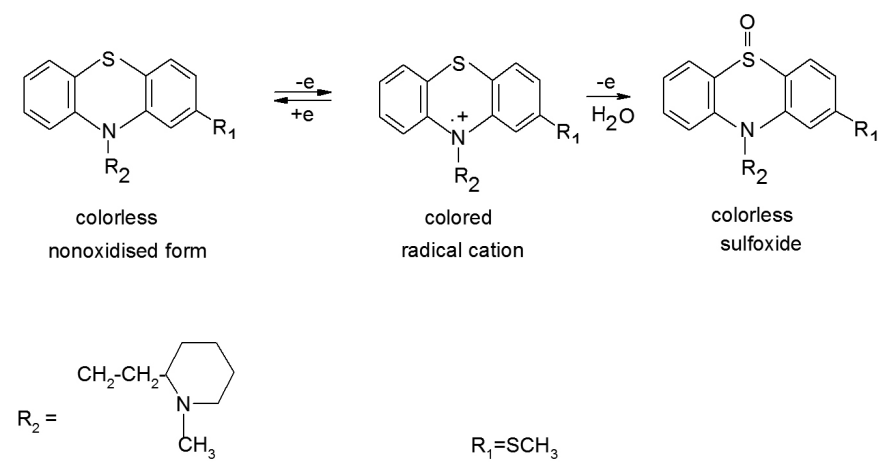

Scheme 2: The probable mechanism for oxidation of phenothiazine derivative.

\section{Effects of temperature and reaction time}

Keeping other conditions constant, the effect of temperature on absorbance was studied. The reaction between TRH and NBS was found to be instantaneous. However, the reaction is complete within $10 \mathrm{~min}$ at room temperature $\left(25 \pm 2{ }^{\circ} \mathrm{C}\right)$, but 15 min was sufficient to get maximum intensity and remaining stable for at least $120 \mathrm{~min}$. Therefore, $15 \mathrm{~min}$ time at room temperature have been selected for further experiments.

\section{Effect of acids}

Hydrochloric acid was the medium of choice for the oxidation of TRH by NBS as well as the latter's determination with the two dyes. Since nitric acid and sulphuric acid are oxidizing in nature, glacial acetic acid and hydrochloric acid were tried. It was found that best results were obtained with $2.0 \mathrm{ml}$ of 2.0 $\mathrm{M}$ hydrochloric acid.

\section{Effect of $\mathrm{N}$-bromosuccinimide}

The effect of oxidant concentration was studied by adding different volumes of $0.05 \%$ NBS solution to a constant amount of TRH $(6.4 \mu \mathrm{g} / \mathrm{ml})$. It was observed that the maximum color intensity was obtained with $0.4 \mathrm{ml}$ of NBS (Fig. 1), after which further increase in volume resulted in a decrease of absorbance. Thus, $0.4 \mathrm{ml}$ of the NBS was sufficient to reach with the maximum drug concentration in the Beer's range.

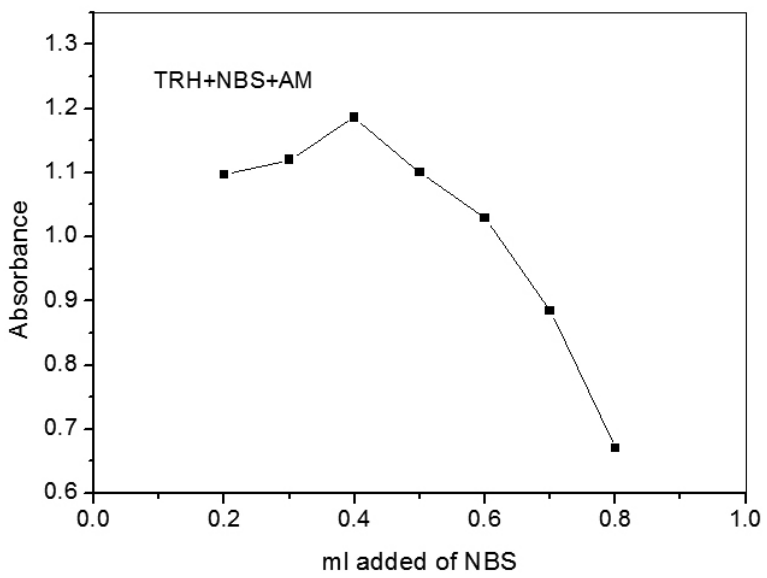

Fig. 1. Effect of added $0.05 \%$ NBS on the development of the reaction product of $\left(6.4 \mathrm{mg} \mathrm{ml}^{-1}\right) \mathrm{TRH}$ and AM.

\section{Effect of dye concentration}

The effect of the dye-concentration on the intensity of the color developed at the selected wavelengths was studied separately by measuring the absorbance's of final solutions resulting from reaction mixtures containing a fixed concentration of TRH and various amounts of acid dyes $(0.5-5 \mathrm{ml})$. The 
use of $0.9 \mathrm{ml}$ of $2.0 \times 10^{-3} \mathrm{M} \mathrm{AM}$ and $0.8 \mathrm{ml}$ of $1.0 \times 10^{-3} \mathrm{M} \mathrm{MB}$, were found to be necessary to produce constant absorbance values.

\section{b- $\quad$ Ion-pair methods using BPB and BTB}

Extractive spectrophotometric procedures due to their sensitivity are widely used in the assay of drugs and hence, ion-pair extractive spectrophotometry has received a considerable attention for the quantitative determination of many pharmaceutical compounds ${ }^{30-34}$. TRH reacts with BPB and BTB in an acidic buffer to give methylene chloride soluble ion-pair complexes, which exhibit absorption maxima at 405 and $408 \mathrm{~nm}$ for BPB and BTB, respectively. Under the experimental conditions, the colorless blanks have practically negligible absorbance, thereby permitting good analytical conditions for the quantitative determination of TRH.

\section{Effect of buffer and $p H$}

Optimum reaction conditions for the quantitative determination of ionpair complexes were established via a number of preliminary experiments. It was observed that the effective extraction of the complex depended on the type of buffer used and its $\mathrm{pH}$. The effect of $\mathrm{pH}$ was studied by extracting the colored complexes in presence of various buffers viz., $\mathrm{KCl}-\mathrm{HCl}(\mathrm{pH}=1.0-2.2)$, potassium hydrogen phthalate- $\mathrm{HCl}(\mathrm{pH}=2.2-3.6), \mathrm{NaOAc}-\mathrm{HCl}(\mathrm{pH}=1.99-$ $4.92)$ and $\mathrm{NaOAc}-\mathrm{AcOH}(\mathrm{pH}=3.72-5.57)$. It was noticed that the maximum color intensity and constant absorbance's were observed in $\mathrm{KCl}-\mathrm{HCl}$ buffer (Clark and Lubs) of $\mathrm{pH} 1.6$ for both dyes. Hence, Clark and Lubs buffer of pH 1.6 was used for all subsequent measurements in both methods (Fig. 2). Further, $2.0 \mathrm{ml}$ of $\mathrm{KCl}-\mathrm{HCl}$ buffer of $\mathrm{pH} 1.6$ for both $\mathrm{BPB}$ and BTB gave maximum absorbance's and reproducible results.
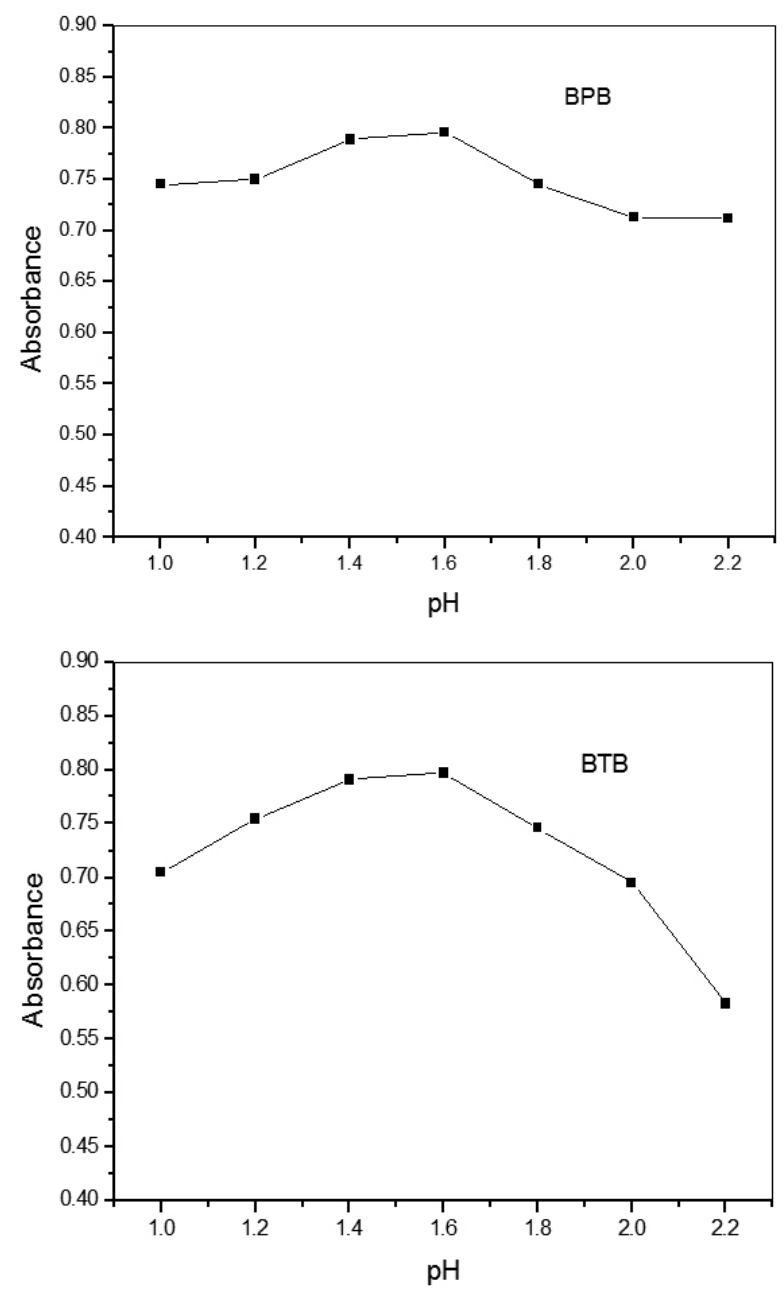

Fig. 2. Effect of $\mathrm{pH}$ on the absorbance of the reaction products with BPB, and BTB.

\section{Choice of organic solvent}

The effect of solvents such as chloroform, ethyl acetate, methylene chloride, benzene and carbon tetrachloride on the color formation was studied. The most convenient solvent found to produce the highest absorbance, extraction power and stability of color was methylene chloride. The study reveals that a volume ratio of 1: 1 (aqueous: organic) was the most suitable for ion-pair extraction.

\section{Effect of time and temperature}

The optimum reaction time was investigated by following the color development at ambient temperature $\left(25 \pm 5^{\circ} \mathrm{C}\right)$. Complete color intensity was attained after $2.0 \mathrm{~min}$ of mixing for all complexes. Raising the temperature up to $30^{\circ} \mathrm{C}$ has no effect on the absorbance of the formed complexes, whereas above $30^{\circ} \mathrm{C}$, the drug concentration was found to increase due to volatile nature of the methylene chloride. As a result, the absorbance's of the colored complexes increased. The resulting ion-pair complexes were found to be stable up to $24 \mathrm{~h}$ at room temperature.

\section{Effect of dyes concentration}

The effect of dyes concentration were studied separately by measuring the absorbance's of final solutions resulting from reaction mixtures containing a fixed concentration of TRH and various amounts of the dyestuff. The results showed that $2.0 \mathrm{ml}$ of $1 \times 10^{-3} \mathrm{M}$ dyestuff was sufficient to produce maximum and reproducible color intensity. Excess of these dyes did not have any effect either on the color of the ion-pair complexes or on the absorbance.

\section{Effect of sequence and time of shaking}

The most favorable sequence was drug-buffer-dye-solvent for the production of the highest color intensity and the shortest time for developing maximum absorbance, while the other sequences require longer time and produce lower absorbance values. The time of shaking for extraction of ionpair complexes was studied and found that the absorbance of the extract remains constant between 0.5-5.0 min. Thus, 2.0 min shaking time was utilized as an optimum value throughout the experiment. The ion-pair complexes were quantitatively recovered in one extraction only.

\section{Stoichiometric relationship}

The stoichiometric ratio between TRH and reagents in oxidation or ion-pair reactions was checked by Job's continuous variation method. For each method, a series of solutions was prepared in which the total volume of the drug and reagents were kept at $2.0 \mathrm{ml}$, and the procedure was completed as described under recommended procedures and calibration curves. The absorbance of each solution was plotted against the mole fraction of drug, (Fig. 3). The results showed that the reactions proceeded in the ratio of $1: 3$ for oxidation but $1: 1$ for ion-pair complex formation.

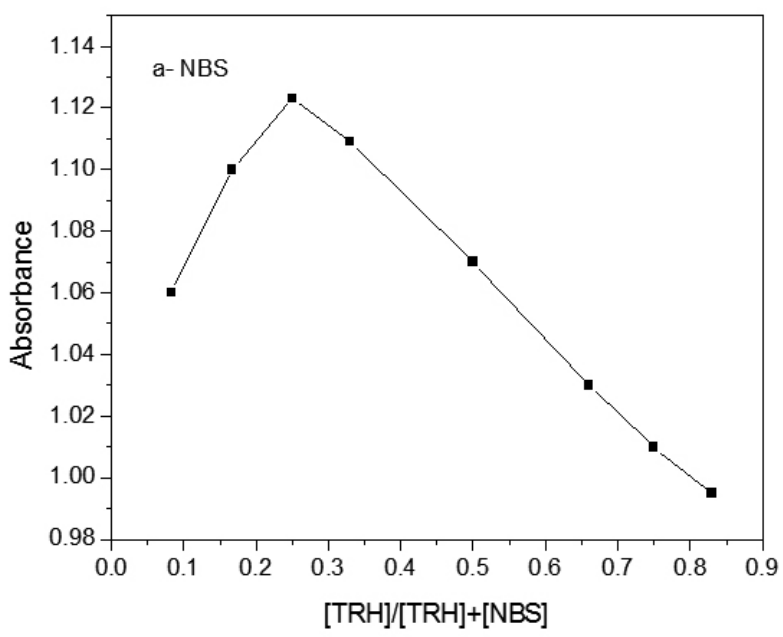



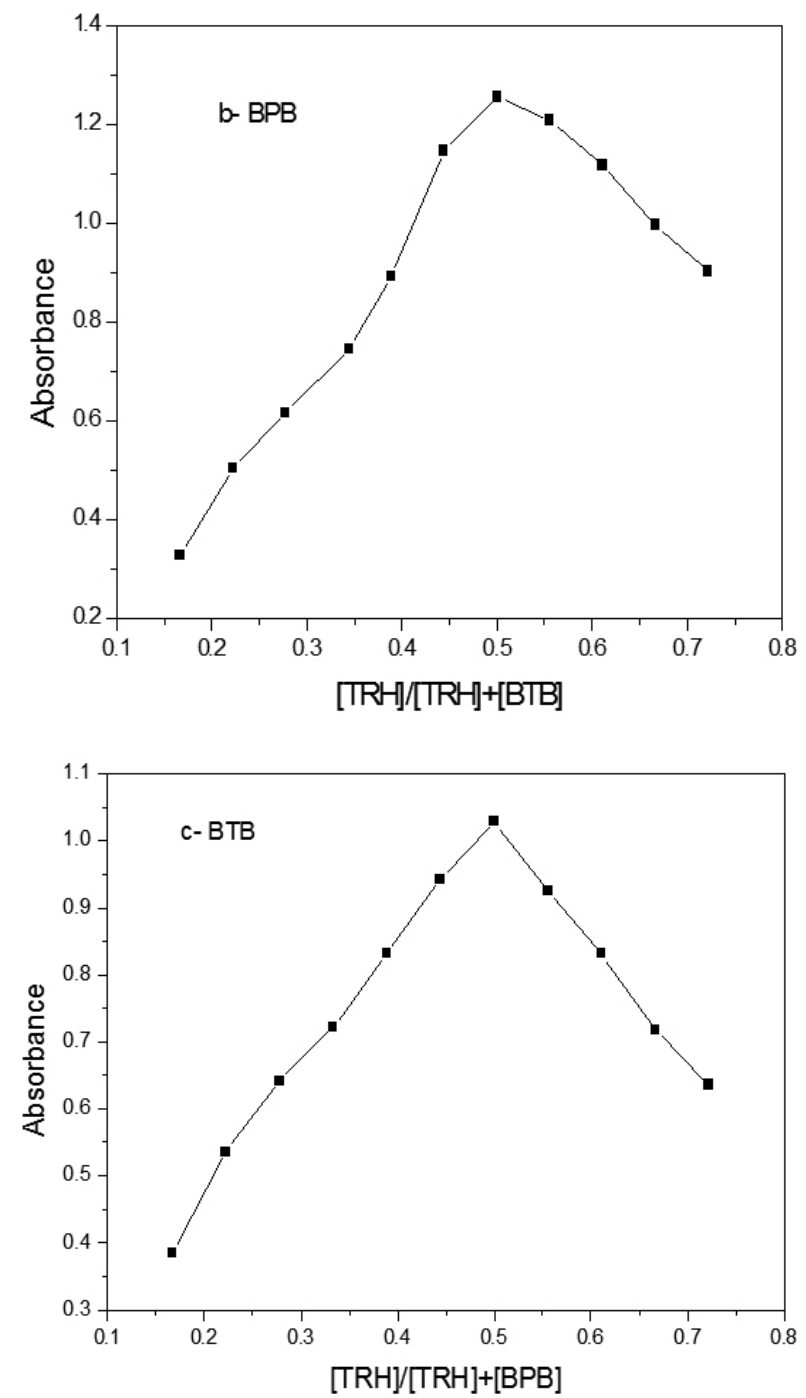

Fig. 3. Job's plot of continuous variations of TRH with a- NBS, b- BPB and c- BTB.

\section{Analytical data}

The linear calibration graphs for TRH were obtained under the optimum experimental conditions. The analytical results obtained from this investigation are summarized in Table 1 . The calibration data were fitted by least square treatment and the regression equations and a linear relationship was found between absorbance and concentration in the ranges given in Table 1. In each case, the correlation coefficient was found to be more than 0.99 , indicating the good linearity of calibration graphs. The apparent molar absorptivities are also presented in Table 1 . The relative sensitivities of the reagents can be determined by comparing the molar absorptivities of the complexes.

\section{Accuracy and precision}

The inter-day repeatability of the proposed methods was studied by performing five independent analyses of TRH in pure form at three different concentration levels on six consecutive days (Table 2). The intraday reproducibility of the proposed method was determined by measuring the drug at three concentration levels within one day five times (Table 2). The reagent solutions were prepared freshly and analyzed as described under recommended procedures and calibration graphs. Data of Table 2, show that within day the relative standard deviations are less than $1.8 \%$ and inter-day relative standard deviations are not exceed $1.2 \%$, which indicates that the proposed methods are highly reproducible.
Table 1. Optical characteristics and statistical data for the regression equation of the proposed methods.

\begin{tabular}{|c|c|c|c|c|}
\hline \multirow[b]{2}{*}{ Parameters } & \multicolumn{2}{|c|}{ Oxidation } & \multicolumn{2}{|c|}{ Ion-pair } \\
\hline & $\mathrm{AM}$ & MB & BPB & ВTB \\
\hline$\lambda_{\max }(\mathrm{nm})$ & 520 & 660 & 408 & 405 \\
\hline $\begin{array}{l}\text { Beer's law limit }(\mu \mathrm{g} / \\
\mathrm{ml})\end{array}$ & $0.8-4.8$ & $0.8-5.6$ & $4-24$ & $4-24$ \\
\hline $\begin{array}{c}\text { Molar absorptivity (1/ } \\
\text { mol cm) }\end{array}$ & $1.29 \times 10^{4}$ & $1.08 \times 10^{4}$ & $1.98 \times 10^{4}$ & $1.93 \times 10^{4}$ \\
\hline $\begin{array}{l}\text { Sandell's sensitivity } \\
\left(\mu \mathrm{g} / \mathrm{cm}^{2}\right)\end{array}$ & 0.0318 & 0.0378 & 0.0205 & 0.0211 \\
\hline $\begin{array}{l}\text { Correlation coefficient } \\
\text { (r) }\end{array}$ & 0.9994 & 0.9964 & 0.9995 & 0.9989 \\
\hline \multicolumn{5}{|l|}{$\begin{array}{c}\text { Linear regression } \\
\text { equation }^{\mathrm{a}}\end{array}$} \\
\hline $\mathrm{S}_{\mathrm{y} / \mathrm{x}}$ & 0.0477 & 0.0189 & 0.0101 & 0.0269 \\
\hline Slope (b) & 0.18 & 0.1123 & 0.0465 & 0.0466 \\
\hline Intercept (a) & 0.4896 & 0.6996 & 0.056 & -0.0463 \\
\hline S.D. of slope $\left(\mathrm{S}_{\mathrm{b}}\right)$ & 0.0188 & $7.50 \times 10^{-3}$ & $8.04 \times 10^{-4}$ & $\begin{array}{c}2.13 \times 10^{-} \\
3\end{array}$ \\
\hline S.D. of intercept $\left(\mathrm{S}_{\mathrm{a}}\right)$ & 0.1012 & 0.0403 & $4.31 \times 10^{-3}$ & 0.0114 \\
\hline $\mathrm{LOD}(\mu \mathrm{g} / \mathrm{ml})$ & 0.0626 & 0.0691 & $4 \times 10^{-3}$ & $\underset{3}{1.32 \times 10^{-}}$ \\
\hline LOQ $(\mu \mathrm{g} / \mathrm{ml})$ & 0.2087 & 0.2304 & $7 \times 10^{-3}$ & 0.0231 \\
\hline
\end{tabular}

${ }^{a} \mathrm{~A}=\mathrm{a}+\mathrm{bC}$, where $\mathrm{A}$ is the absorbance and $\mathrm{C}$ is the concentration of TRH in $\mu \mathrm{g} / \mathrm{ml}$

\section{Application to analysis of tablets}

The proposed methods were successfully applied to the determination of TRH in representative tablets and the results are summarized in Table 3. For the brands/doses examined, the methods gave results which were in agreement with the declared content.

The performance of the proposed method was judged by calculating the student $t$ - and $F$-values ${ }^{35}$. At $95 \%$ confidence level, the calculated $t$ - and $F$-values did not exceed the theoretical values as evident from Table 3 . Hence, it was concluded that there is no significant difference between the proposed and official method ${ }^{7}$ with respect to accuracy and precision. Moreover, to check the validity of the proposed methods, we applied the standard addition method by adding TRH to the previously analyzed tablets. The recovery of TRH was calculated by comparing the concentration obtained from the spiked mixtures with those of the pure drug and the recoveries of added quantity were found to be more than $98 \%$. This indicates that there is no interference from any excipients, which are present in tablets. These results are given in Table 4.

\section{Analysis of a human sample}

Phenothiazines are used as antipsychotic drugs and as reagents to determine the $\mathrm{Hb}$ in biological fluids and tissues ${ }^{36,37}$, but over dosage can cause death ${ }^{37}$, ${ }^{38}$, so the quantitative assessment of added thioridazine in serum and urine of healthy human beings is also determined as shown in Table 5. High accuracy and good recovery are obtained, which indicates that the proposed methods can be successfully applied to recover thioridazine e in human samples.

\section{Interference study}

The commonly used excipients and additives which often accompany TRH in its dosage forms, such as (starch, lactose, glucose, sugar, talc, sodium chloride and magnesium stearate) was studied. The results indicated that there is no interference from the degradation, indicating a high selectivity for determining the studied TRH in its dosage forms. 
Table 2. Evaluation of intra-day and inter-day accuracy and precision of the proposed methods.

\begin{tabular}{|c|c|c|c|c|c|c|c|}
\hline \multirow[b]{2}{*}{ Method } & \multirow{2}{*}{$\begin{array}{c}\text { TRH } \\
\text { Taken } \\
\mu \mathrm{g} / \mathrm{ml}\end{array}$} & \multicolumn{3}{|c|}{ Intra-day accuracy and precision } & \multicolumn{3}{|c|}{ Inter-day accuracy and precision } \\
\hline & & $\begin{array}{l}\text { TRH found }{ }^{\mathrm{a}} \text {, } \\
\mu \mathrm{g} / \mathrm{ml}\end{array}$ & $\begin{array}{c}\mathrm{RE}^{\mathrm{b}} \\
\%\end{array}$ & $\begin{array}{c}\text { RSD, } \\
\%\end{array}$ & $\begin{array}{c}\text { TRH found, } \\
\mu \mathrm{g} / \mathrm{ml}\end{array}$ & $\begin{array}{c}\mathrm{RE}, \\
\%\end{array}$ & $\begin{array}{c}\text { RSD, } \\
\%\end{array}$ \\
\hline \multirow{3}{*}{$\begin{array}{c}\text { NBS } \\
+ \\
\mathrm{AM}\end{array}$} & 2.4 & 2.399 & $-2 \times 10^{-3}$ & 1.034 & 2.4 & 0.00 & 0.7480 \\
\hline & 4 & 4.001 & 0.03 & 1.805 & 3.999 & $-2 \times 10^{-3}$ & 0.8425 \\
\hline & 4.8 & 4.799 & $-6 \times 10^{-3}$ & 0.852 & 4.799 & $-2 \times 10^{-3}$ & 0.3031 \\
\hline \multirow{3}{*}{$\begin{array}{c}\text { NBS } \\
+ \\
\text { MB }\end{array}$} & 1.6 & 1.599 & $-2 \times 10^{-3}$ & 1.022 & 1.599 & $-2 \times 10^{-3}$ & 1.2435 \\
\hline & 3.2 & 3.199 & $-2 \times 10^{-3}$ & 0.6466 & 3.199 & $-4 \times 10^{-3}$ & 0.7498 \\
\hline & 4 & 3.999 & $-4 \times 10^{-3}$ & 0.4403 & 3.999 & $-6 \times 10^{-3}$ & 0.4504 \\
\hline \multirow{3}{*}{$\begin{array}{c}\text { TRH } \\
+ \\
\text { BPB }\end{array}$} & 8 & 7.999 & -0.004 & 0.8551 & 7.999 & -0.002 & 1.0958 \\
\hline & 16 & 15.999 & -0.004 & 0.5892 & 15.998 & -0.01 & 0.4546 \\
\hline & 24 & 23.999 & -0.004 & 1.0246 & 23.999 & -0.004 & 0.4619 \\
\hline \multirow{3}{*}{$\begin{array}{c}\text { TRH } \\
+ \\
\text { BTB }\end{array}$} & 8 & 7.999 & 0.9296 & -0.002 & 7.999 & -0.004 & 0.7796 \\
\hline & 16 & 15.999 & 1.116 & -0.002 & 15.999 & -0.004 & 0.8794 \\
\hline & 24 & 24.0 & 0.7190 & 0.0 & 23.999 & -0.004 & 0.9936 \\
\hline
\end{tabular}

${ }^{\mathrm{a}}$ Mean value of five determinations.

${ }^{b} R E$ : Relative error.

Table 3. Recovery of TRH in tablets formulation using the proposed methods.

\begin{tabular}{|c|c|c|c|c|c|}
\hline \multirow{2}{*}{ Formulation } & \multicolumn{5}{|c|}{ Found $^{\mathrm{a}}$ (\% of nominal amount \pm RSD) } \\
\cline { 2 - 5 } & NBS+AM & NBS+MB & TRH+BPB & TRH+BTB & Reference method \\
\hline \multirow{2}{*}{$\begin{array}{c}\text { Thiozine } \\
25 \mathrm{mg} / \mathrm{tablet}\end{array}$} & $98.69 \pm 1.66$ & $97.93 \pm 2.42$ & $98.92 \pm 1.51$ & $99.92 \pm 0.78$ & \multirow{2}{*}{$99.88 \pm 1.32$} \\
\cline { 2 - 5 } & $\mathrm{t}=1.159$ & $\mathrm{t}=2.190$ & $\mathrm{t}=2.007$ & $\mathrm{t}=1.166$ & \\
\cline { 2 - 5 } & $\mathrm{F}=1.581$ & $\mathrm{~F}=3.361$ & $\mathrm{~F}=1.308$ & $\mathrm{~F}=2.863$ & \\
\hline
\end{tabular}

${ }^{a}$ Mean value of five determinations.

Tabulated $t$-value at the $95 \%$ confidence level is 2.77 .

Tabulated $F$-value at the $95 \%$ confidence level is 6.39 .

Table 4. Results of the recovery study by the standard addition method.

\begin{tabular}{|c|c|c|c|c|c|c|}
\hline Formulation & Method & $\begin{array}{l}\text { Amount of drug in } \\
\text { formulation, } \mu \mathrm{g}\end{array}$ & $\begin{array}{l}\text { Amount of } \\
\text { pure drug } \\
\text { added, } \mu \mathrm{g}\end{array}$ & $\begin{array}{l}\text { Total found, } \\
\qquad \mu \mathrm{g}\end{array}$ & $\begin{array}{c}\text { Recovery of pure } \\
\text { drug, } \\
\%\end{array}$ & $\begin{array}{c}\mathrm{RSD}^{*}, \\
\%\end{array}$ \\
\hline \multirow{12}{*}{$\begin{array}{c}\text { Thiozine, } 25 \mathrm{mg} / \\
\text { tablet }\end{array}$} & \multirow{3}{*}{$\begin{array}{c}\text { NBS } \\
+ \\
\text { AM }\end{array}$} & \multirow{3}{*}{1.6} & 1.6 & 3.175 & 99.214 & 1.1602 \\
\hline & & & 2.4 & 3.952 & 98.814 & 1.5213 \\
\hline & & & 3.2 & 4.721 & 98.374 & 2.067 \\
\hline & \multirow{3}{*}{$\begin{array}{l}\text { NBS } \\
+ \\
\text { MB }\end{array}$} & \multirow{3}{*}{2.4} & 1.6 & 3.982 & 99.564 & 0.6518 \\
\hline & & & 2.4 & 4.744 & 98.845 & 1.4900 \\
\hline & & & 3.2 & 5.549 & 99.11 & 1.1390 \\
\hline & \multirow{3}{*}{$\begin{array}{c}\text { TRH } \\
+ \\
\text { BPB }\end{array}$} & \multirow{3}{*}{8} & 4 & 11.792 & 98.27 & 2.2493 \\
\hline & & & 8 & 15.867 & 99.17 & 1.7831 \\
\hline & & & 12 & 19.7591 & 98.49 & 2.2484 \\
\hline & \multirow{3}{*}{$\begin{array}{c}\text { TRH } \\
+ \\
\text { BTB }\end{array}$} & \multirow{3}{*}{8} & 4 & 11.774 & 98.12 & 2.7693 \\
\hline & & & 8 & 15.786 & 98.66 & 2.6062 \\
\hline & & & 12 & 19.820 & 99.10 & 1.4701 \\
\hline
\end{tabular}

"Five independent analyses.

Table 5. Recovery of TRH in serum and urine $(n=5, t=2.78)$

\begin{tabular}{|c|c|c|c|c|c|c|c|}
\hline \multirow[b]{2}{*}{ Method } & \multirow[b]{2}{*}{$\begin{array}{c}\text { Added, } \\
\mu \mathrm{g} / \mathrm{ml}\end{array}$} & \multicolumn{3}{|c|}{ Serum } & \multicolumn{3}{|c|}{ Urine } \\
\hline & & $\begin{array}{l}\text { Found, } \\
\mu \mathrm{g} / \mathrm{ml}\end{array}$ & $\begin{array}{c}\text { Recovery, } \\
\%\end{array}$ & $\begin{array}{c}\text { RSD }^{*}, \\
\%\end{array}$ & $\begin{array}{l}\text { Found, } \\
\mu \mathrm{g} / \mathrm{ml}\end{array}$ & $\begin{array}{c}\text { Recovery, } \\
\%\end{array}$ & $\begin{array}{c}\mathrm{RSD}_{\%}^{*}, \\
\end{array}$ \\
\hline \multirow{3}{*}{$\begin{array}{c}\text { NBS } \\
+ \\
\text { AM }\end{array}$} & 1.6 & 1.5999 & 99.994 & 1.235 & 1.6408 & 102.55 & 2.236 \\
\hline & 2.4 & 2.3998 & 99.994 & 0.896 & 2.3990 & 99.996 & 1.711 \\
\hline & 3.2 & 3.1999 & 99.998 & 2.224 & 3.1998 & 99.996 & 2.452 \\
\hline \multirow{3}{*}{$\begin{array}{c}\text { NBS } \\
+ \\
\text { MB } \\
\end{array}$} & 2.4 & 2.3999 & 99.998 & 0.517 & 1.6189 & 101.18 & 1.571 \\
\hline & 3.2 & 3.1998 & 99.996 & 1.292 & 3.1998 & 99.996 & 0.804 \\
\hline & 4.0 & 3.999 & 99.998 & 1.854 & 3.999 & 99.996 & 0.591 \\
\hline \multirow{3}{*}{$\begin{array}{c}\text { TRH } \\
+ \\
\text { BPB }\end{array}$} & 8 & 8.153 & 101.917 & 1.079 & 7.995 & 99.49 & 1.101 \\
\hline & 16 & 15.765 & 98.532 & 2.021 & 15.944 & 99.654 & 0.788 \\
\hline & 24 & 23.712 & 98.801 & 2.320 & 23.802 & 99.178 & 1.249 \\
\hline \multirow{3}{*}{$\begin{array}{c}\text { TRH } \\
+ \\
\text { BTB }\end{array}$} & 8 & 7.977 & 99.717 & 1.935 & 7.9689 & 99.611 & 1.727 \\
\hline & 16 & 16.117 & 100.734 & 2.091 & 16.038 & 100.24 & 1.721 \\
\hline & 24 & 23.960 & 99.833 & 1.860 & 23.801 & 99.169 & 1.761 \\
\hline
\end{tabular}

${ }^{*}$ Five independent analyses. 


\section{Robustness}

The robustness of the proposed method was evaluated by using the different instruments by two different analysts under the same optimized conditions. The obtained results were found to be reproducible, since there was no significant difference between the results obtained by the two analysts. Thus, the proposed methods could be considered robust.

\section{CONCLUSION}

The proposed methods have the advantages of simplicity and rapidity for the determination of TRH in both pure and in pharmaceutical preparations. It can also be evaluated accurately in human serum and urine samples. The reagents utilized in the proposed methods are cheaper, readily available and the procedures do not involve any critical reaction conditions or tedious sample preparation. The utility of the proposed methods for routine quality control is well established by the assay of TRH in various pharmaceutical dosage forms.

\section{REFERENCES}

1. Gaitania, C.M., Martinezb, A.S., Bonato, P.S., J. Pharm. Biomed. Anal. 36, 601-607, (2004)

2. Abdel-Moety, E.Z., Al-Rashood, K.A., Florey, K.A., Analytical Profiles of Drug Substances, Academic Press, New York, Vol. 18, (1988).

3. Farhadi, K., Teimouri, G., Talanta, 65, 925-929 (2005).

4. Karpinska, J., J. Trace Microprobe Tech. 14, 389-397 (1996).

5. Raj, J.B., Gowda, H.S., Analyst 120, 1815 - 1817 (1995).

6. Palacios J., Sepúlveda M.R., Lee A.G., Mata A.M., Biochem. 43, 23532358 (2004).

7. British Pharmacopoeia, The Pharmceutical Press, London, pp. 473 (1993).

8. Shahrokhian S., Ghalkhani M., Adeli M., Amini, M.K., Biosens. Bioelectron. 24, 3235-3241 (2009).

9. Biryol J., Dermis S., Turkish J Chem, 22, 325-333 (1998).

10. Zimova N., Nemec I., Zima J., Talanta 33, 467-470 (1986).

11. Allender W.J., J. Chromatogr. 23, 541-545 (1985).

12. Mehta A.C., Analyst 106, 1119-1122 (1981).

13. Geiser F., Schultz M., Betz L., Shaimi M., Lee J., Champion W., J. Chromatogr. A 865, 227-233 (1999).

14. Xiong C., Ruan J., Cai Y., Tang Y., J. Pharm. Biomed. Anal. 49, 572-578 (2009).

15. Kirchherr H., Kühn-Velten W.N., J. Chromatogr. B. 843, $100-113$ (2006).

16. Jortani S.A., Poklis A., J. Anal. Toxicol. 17, 374-377 (1993).

17. Davis C.M., Harrington C.A., J. Chromatogr. Sci. 22, $71-74$ (1984).

18. Muusze R.G., Huber J.F.K., J. Chromatogr. Sci. 12, $779-787$ (1974).

19. Kojlo A., Michalowski J., Wolyniec E.B., J. Pharm. Biomed. Anal. 22, 85-91 (2000).

20. Lin C.E., Ko T.C., Kuo C.M., Trapp O., Lin W.Y., Lin C.H., Wu J.C., Liu Y.C., Electrophoresis, 30, 3071-3078 (2009).

21. Mohamed F.A., Mohamed H.A., Hussein S.A., Ahmed S.A., J. Pharm. Biomed. Anal. 39 139-146 (2005).

22. Mohamed F.A., Anal. Lett. 28, 2491-2501 (1995).

23. Basavaiah K., Krishnamurthy G., Annali di Chim. 89, 623-629 (1999).

24. Tarasiewicz M., Wolyniec E., Puzanowska-Tarasiewicz H., Pharmazie, 53, 151-155 (1998).

25. Tarasiewicz M., Kuz'micka L., Anal. Lett. 29, 929-936 (1996).

26. Aman T., Ali A., Khokhar I., Rashid A., Mikrochim. Acta 126, 295-300 (1997).

27. Minakata K., Suzuki O., Ishikawa Y., Seno H., Harada N., Forensic Sci. Int. 52, 199-210 (1992).

28. Katritzky A.R., Boulton A.J., Advances in Heterocyclic Chemistry, Vol 9, Academic Press, New York, London, pp. 342-343 (1968).

29. Seetharamappa J., Motohashi N., Kovala-Demertzi D., Curr. Drug Targets 7, 1107-1121 (2006).

30. El-Didamony A.M., Arch. Pharm. Chem. Life Sci. 338, 190-197 (2005).

31. El Sherif Z.A., Mohamed A.O., Walash M.I., Tarras F.M., J. Pharm. Biomed. Anal. 22, 13-23 (2000).

32. Çağlar S., Önal A., J. Anal. Chem. 65, 239-243 (2010).

33. Amin A.S., Dessouki H.A., Moustafa M.M., Ghoname M.S., Chem. Pap. 63, 716-722 (2009).

34. El-Didamony A.M., Moustafa M.A., Arab. J. Chem. 3, 265-270 (2010).

35. Miller J.C., Miller J.N., "Statistics in Analytical Chemistry" 3th Edn., Ellis Horwood, Chichester, chapter 3 (1993).
36. Martindale, The Extra Pharmacopeia, 29th Ed, Pharmaceutical Press, London, pp. 706 (1989).

37. The Pharmaceutical Codex Incorporation 9 the British Pharmaceutical Codex, 11th Ed., Pharmaceutical Press, London, (1979).

38. American Medical Association, New Drugs Chicago, pp. 121 (1967). 